\title{
The heavy metal hazard of undiscovered World War I and II graves in Poland
}

\author{
Kaczmarek B.* \\ Institute of Archaeology, Adam Mickiewicz University in Poznan, Wieniawskiego 1, 61-712 Poznan, Poland \\ Received: 14/03/2018, Accepted: 13/07/2018, Available online: 26/09/2018 \\ *to whom all correspondence should be addressed: e-mail: bk34033@st.amu.edu.pl \\ https://doi.org/10.30955/gnj.002680
}

\begin{abstract}
The purpose of this research is to identify and characterize the poorly investigated problem of heavy metal contamination originating from World War I and II mass graves. Chemical elements pass systematically into the soil from metal weapons, buttons, badges, and other objects. As a result, the soil and groundwater become highly saturated with heavy metals relative to metals from communal waste. A review of previous analyses of the areas surrounding localized graves in southeast Poland revealed chemicals leached from burials to have a significant impact on the environment and groundwater. This review highlights the danger posed by mass graves that are frequently located near human settlements and rivers. However, the exact locations of the majority of mass graves are unknown and the heavy metal hazard warrants their identification and reburial in an appropriate place.
\end{abstract}

\section{Introduction}

The close proximity of burials concentrated in a small area is known to have a negative influence on human health and the surrounding environment (Zychowski et al., 2000). This is because burials can cause an increased concentration of certain chemical elements in the soil and groundwater. When building of a new cemetery, developers must follow clearly defined norms regarding location - specifically, the soil should have adequate permeability and the location should be sufficiently distant from groundwater and watercourses, as well as human settlement (Zychowski et al., 2015).

The location of mass graves is, however, mostly accidental and they tend to be situated in remote, uninhabited and forested areas. Such graves are often connected with a more rapid spread of heavy metals $(\mathrm{Cd}, \mathrm{Cr}, \mathrm{Cu}, \mathrm{Ni}$, $\mathrm{Zn}$ ) and other chemical substances, such as amino acids, cadaverous poison, different ions and manganate. Furthermore, many variables influence the spread of heavy metals, including the depth of groundwater, type of soil, landform, forestation and distance from watercourses.
Southeast Poland comprises one of the largest areas with unknown mass graves from World Wars I and II. Unknown mass graves are dangerous for a human health and the surrounding environment because chemical elements from metal weapons, buttons, badges, and other objects systematically penetrate the soil and groundwater over time. As a result, in many cases the soils of mass graves are several times more saturated with heavy metals relative to metals originating from communal waste. Due to the potential contamination from these graves, they should be located, exhumed, freed of the contaminating metal elements and re-buried in an appropriate place. The metal elements should be safeguarded and after conservation, displayed in a local museum.

The Commission for the Prosecution of Crimes against the Polish Nation in Warsaw (IPN) currently is carrying out investigations to locate mass graves from World War II. The initiation of an investigation is based on witness testimony. However, in many cases the initiation of an investigation by the Commission is prevented by contradictory testimonies. Furthermore, investigations are conducted many years after the incident that memory of the details is often fuzzy or complemented by what witnesses have heard from others at a later time. Such false memories include recollections of the locations of mass graves.

\section{Characteristic of mass graves}

A mass grave is a burial within a small area that contains a large number of people without coffins who died in a similar manner or at the same time as a result of a sudden, tragic death. Mass graves are associated primarily with victims of wars, natural disasters, as well as with victims of a pandemic (Zychowski, 2008).

\section{Dangerous heavy metals in the environment}

Heavy metals are naturally occurring chemical elements in the environment. Small amounts can be found in soil, water and living organisms. When standards are exceeded for a long period, they become poison. Symptoms of poisoning are not always immediately visible - they may become observable only after many years or even in the 
next generation. Factories working with metal try to limit the entry of pollutants into the environment (Romanowska-Duda, 2013). A modern problem is the pollution of waters with heavy metals. The hazard associated with various substances in water has been divided into three categories (Gdansk University, 2010), of which the presence of heavy metals is defined as being directly harmful to health. The second group contain nuisance compounds, such as zinc compounds, chlorides or copper compounds. The third group includes desired or undesired compounds that may be present in various concentrations in water (e.g., fluorine, iodine). In Poland, water quality is mediated by the "Water Framework Directive" (23.10.2000-2000/60/EC) established by the European Parliament, which requires monitoring and improvement of surface waters status. In addition, the same directive, together with the Polish Water Law $(18 / 07 / 2001$ Journal of Laws No. 115) protects underground water, from which drinking water is obtained (Gdansk University, 2010).

\section{Description of heavy metals}

The concentration of heavy metals depends on many factors. First are the physical and chemical properties of each metal, but also the presence of impurities in the water, the $\mathrm{pH}$ value and the oxidation-reducing potential. Heavy metals may be present in the environment as soluble or insoluble (Romanowska-Duda, 2013). Heavy metals enter the natural environment via water and the chemical compounds it contains because they can be ingested. The activity of metals varies depending on the type of metal and can thus affect the amount of their concentration in water, as well as the period of percolation into the environment (Piontek et al., 2014). The degree of pollution and impact on living organisms depend mainly on chemical form, type of element, as well as the physical condition of the organism (Kabata-Pendias, Pendias, 1999).

Arsenic (As) is one of the chemical elements that is a heavy metal. Anthropogenic routes of arsenic pollution in the environment come from the sewage of industrial pharmaceutical plants, tanneries, producing dyes, or from steelworks and mine waters. Synthetic pesticides used in plant crops can also contain arsenic. As toxicity depends primarily on the chemical connection in which it occurs, the presence of other elements in the diet may enhance or weaken the action of arsenic, as will the age and sex of the exposed people. Arsenic poisoning damages the central nervous system and skin. Small but steady doses of As cause muscle weakness, loss of appetite, nausea, mucositis and skin diseases. The permissible dose of arsenic in drinking water is $0.010 \mathrm{mg} / \mathrm{l}$, and the lethal dose is $70-180 \mathrm{mg}$.

Cadmium ( $\mathrm{Cd}$ ) is a heavy metal that commonly occurs in the environment. Anthropogenically, it is primarily used in the metallurgical industry. Furthermore, items made of plastics, such as PVC, also contain a large extent of $\mathrm{Cd}$. Cadmium can enter the body through ingested water and cause damage because even small concentrations of this metal are harmful. This heavy metal accumulates in the liver, kidneys, pancreas, thyroid and hair. The concentration of $\mathrm{Cd}$ in drinking water should not exceed $0.005 \mathrm{mg} / \mathrm{l}$.

Lead $(\mathrm{Pb})$ is the most common heavy metal in water. This metal enters water via industrial sewage, from anticorrosive coatings, and other objects in the production of which lead was used. It is a chemical element which has extremely toxic properties. Additionally, it can accumulate in human bones. The lead content in drinking water should not exceed $0.025 \mathrm{mg} / \mathrm{l}$. Exposing the body to higher daily doses of lead leads to severe poisoning, called saturnism, which can even end in death.

Chromium ( $\mathrm{Cr}$ ) is one of the heavy metals often found in drinking water and its concentration increases with municipal pollution. As a chemical compound, it can occur in a benign trivalent form and in a hexavalent form, which is toxic and can induce cancer. The maximum concentration of $\mathrm{Cr}$ in drinking water, according to the regulation of the Minister of Health, should not exceed $0.05 \mathrm{mg} / \mathrm{l}$ (Borczyk, 2015).

The group of heavy metals also includes copper, the toxic form of which is copper ion $\left(\mathrm{Cu}^{+2}\right)$. The toxicity of this ion and its concentration in water depends on the hardness and alkalinity of water. Namely, in waters with higher alkalinity and hardness, copper is less toxic. Symptoms of copper poisoning include an increase in glucose, hematocrit, hemoglobin and the number of red blood cells. According to the 2002 Regulation of the Minister of Health, the acceptable concentration in drinking water of copper ions is less than $2 \mathrm{mg} / \mathrm{l}$ (Romanowska-Duda, 2013).

Zinc is an easily soluble heavy metal and its absorption depends on the acidity of the environment. The concentration of this chemical element in water is different depending on the impurities and the type of substrate, as well as on its ionic form, hardness and water $\mathrm{pH}$. The content of zinc in groundwater for domestic use varies from $0.015 \mathrm{mg} / \mathrm{l}$ to $0.08 \mathrm{mg} / \mathrm{l}$. Toxicity of zinc for aquatic organisms is above $0.24 \mathrm{mg} / \mathrm{l}$, and the permissible content of zinc in municipal sewage is $2 \mathrm{mg} / \mathrm{l}$ (Romanowska-Duda, 2013).

\section{Other dangerous metals from mass graves}

Items of clothing, weapons, medals, and personal items made of bronze contain copper and zinc, which in an elevated concentration can cause disturbances in the workings of organisms and plants. Corrosion of these objects also causes other chemical elements, such as iron (Fe), aluminum (Al), silicon (Si) and potassium (K), to leach into the gorund (Mączyńska et al., 2006).

\section{Water quality in a necropolis environment}

Large accumulations of burials within a small region of inadequate soil may threaten the local environment. The human body consists of many components that are released into the ground after death. These are organic 
substances, primarily consisting of proteins that contain protein amino acids (simple) and proteidic amino acids. These amino acids can combine with lipids, carbohydrates, nucleic acids, phosphoric acid, and, importantly, metal atoms. Proteins of living organisms are capable of becoming liquid from a solid state and vice versa. Decomposition of proteins from chains into first molecules takes place by breaking hydrogen then covalent bonds. Often, specific conditions accelerate the breakdown of proteins - such as alkalis, alcohol, concentrated urea solutions, acids, and even temperature. In addition to metals released from the decomposition of the corpse, the amino acid lysine (adipocere) is also dangerous (Zychowski et al., 2005).

\section{How can we measure the heavy metal hazard - methodology}

Research conducted by Zychowski and Lach (Zychowski et al., 2000) has shown that human settlement in close proximity to cemeteries is dangerous because of the compounds that derive from the decomposition of corpses. To investigate this, several areas with different soil chemical properties, substrate permeability and different slope angles were analyzed using ISO 9001 ionic chromatography and a Cx721 digital laboratory meter. The quality of groundwater was assessed by comparing the results of with the permissible content of tested ions, as specified in the Act of May 4, 1990 (Journal of Laws, No. 35, item 205) established by the Minister of Health and Social Welfare. In cases where the permissible content of certain ions were not included in these regulation standards, the standards for the second class of surface water cleanliness was adopted (Zychowski, 2005). In the second class of water, some ions, such as nitrates, sulphates, chlorides, fluorides and ammonium ions, are acceptable (Zychowski, 2005). Samples from the Carpathians, Sandomierska and Oświęcimska Basin, Krakowsko-Częstochowska Upland and Lubelska Upland were collected and analyzed in terms of water conductivity and reaction, nitrate $\left(\mathrm{NO}_{3}{ }^{-}\right)$, sulphates $\left(\mathrm{SO}_{4}{ }^{2-}\right)$, chlorides $\left(\mathrm{Cl}^{-}\right)$, fluorides $\left(\mathrm{F}^{-}\right)$, phosphates $\left(\mathrm{PO}_{4}{ }^{3-}\right)$, potassium $\left(\mathrm{K}^{+}\right)$and ammonium ions $\left(\mathrm{NH}_{4}{ }^{+}\right)$. The largest concentrations of harmful substances were found to be associated primarily with the type of ground and its inclination. Among the surveyed environments, the highest exceedance, as much as 4 times higher than acceptable levels, was detected on ground covered with clays and sand with a considerable inclination on the Kraków-Częstochowa Upland. The subsoil of the Sandomierska and Oświęcimska Basins is characterized by the same geological base - pleistocene terraces mainly covered with sand and miocene clays limiting the free flow of pollutants. The drinking water samples taken from this area exhibited concentrations of chemical compounds two and three times above normal concentrations. The areas of the Lublin Upland and the Carpathians have the best permeability and removal of pollution. Here, the substrate consists primarily of clay and loess (Zychowski et al., 2000).

\section{Where are known WW I and WW II mass graves on the area of Poland?}

On the outskirts of the Puszcza Niepołomicka (a forest near Nipołomice), researchers examined groundwater from a mass grave from the Second World War (Zychowski, 2000, 2005; Zychowski et al., 2005b, 2006). On August 2, 1942, about 700 people were buried there at a depth of approximately 1 meter. The ground surface is characterized by permeable sands over impermeable clays. The area is an old Vistula accumulative terrace from the Baltic glaciation period. The Vistula River flows $3 \mathrm{~km}$ from the site, and the level of ground water near the mass grave ranges by 2.5 meters. The forest consists mainly of pines, with a small admixture of birch. The environment is acidified due to decaying pine needles (Zychowski et al., 2005b). A natural feature of the environment in the burial area is the high content of iron, silicon and manganese in the soil. The concentration of iron is from 40 to 60 $\mathrm{mg} / \mathrm{dm}^{3}$; silicon is $70 \mathrm{mg} / \mathrm{dm}^{3}$, and manganese - from 6 to $18 \mathrm{mg} / \mathrm{dm}^{3}$ (Zychowski, 2000). Samples from a depth of $2.5 \mathrm{~m}$ were examined for the amount of bacteria and organic compounds: cadaverin, bromine, methoxide, chlorfenvinphos, lysine, fosmamidone and chlorocholine chloride. The piezometer was used in the Varian HPLC system. This research found few bacteria and many organic compounds that also threaten the environment, such as chlorfenvinphos - $1.21 \mathrm{~g} / \mathrm{dm}^{3}$ (Zychowski, 2005). The researchers also checked the concentration of metals, in the grave and 200 meters from the burial site. Samples were tested using an atomic spectrometer (Elmer Perkins, 2000). These researchers found the mass grave contaminated groundwater with chemical elements coming from the decomposition of corpses and weaponry. The chlorine and nickel tested from the grave was three times higher than the one tested in the comparative profile. The concentration of phosphorus, sulfur, copper, zinc, nitrogen, potassium and iodine was twice as high. A little higher, however, was the concentration of sodium, calcium, iron, manganese and magnesium (Table 1, Figures 1 and 2). All metal ions from water at the burial site were significantly elevated, in particular: $\mathrm{NH}_{4}{ }^{+}, \mathrm{SO}_{4}{ }^{2-}$, $\mathrm{PO}_{4}^{3-}, \mathrm{F}^{-}, \mathrm{Cl}^{-}, \mathrm{Fe}^{3+}, \mathrm{Mn}^{2+}, \mathrm{Zn}^{2+}, \mathrm{Cu}^{2+}, \mathrm{Al}^{3+}$ (Zychowski et al., 2005b).

Table 1. Concentration of selected chemical elements and background sediments (after Zychowski et al., 2006)

\begin{tabular}{ccccccccc}
\hline & \multicolumn{7}{c}{ Concentration of chemical elements $-\mathbf{m g} / \mathbf{l}$} \\
\cline { 2 - 9 } & $\mathrm{Na}$ & $\mathbf{C a}$ & $\mathbf{M g}$ & $\mathbf{C r}$ & $\mathbf{C u}$ & $\mathbf{C d}$ & $\mathbf{A l}$ & $\mathbf{P b}$ \\
\hline $\begin{array}{c}\text { Mass } \\
\text { grave } \\
\text { profile }\end{array}$ & 14.3 & 15.1 & 10.5 & 18.2 & 7.2 & 0.12 & 0.01 & 1.05 \\
\hline $\begin{array}{c}\text { Back- } \\
\text { ground } \\
\text { profile }\end{array}$ & 17.2 & 15.1 & 10.2 & 0.08 & 4.3 & 0.06 & 0.0 & 0.8 \\
\hline
\end{tabular}

The next studied by Zychowski mass graves is from World War I in Łużna. It is located on the slope of Pustki hill, which facilitates the movement of chemical substances from the grave. The substrate material is composed of heavy clay. The tested water sample came from a covered 
well $50 \mathrm{~m}$ below the burial. A comparative sample was taken from a well located a considerable distance $(250 \mathrm{~m})$ from the grave. An increased content of iodides was found in water, which, however, may be associated with the environment in which the grave is located, not necessarily with the grave itself.

High concentrations of sodium sulphide $\mathrm{Na}_{2} \mathrm{~S}$, as well as $\mathrm{Zn}-0.85 \mathrm{mg} / \mathrm{l}$ (in the comparison sample $0.72 \mathrm{mg} / \mathrm{l}$ ) and $\mathrm{Cu}$ at a concentration of $0.09 \mathrm{mg} / \mathrm{l}$ were found in the sample, where the concentration did not exceed 0.05 $\mathrm{mg} / \mathrm{l}$ in the reference sample. Moreover, in the environment of this mass grave, the norms related to sodium, iron ions, manganese and phosphate ions were definitely exceeded.

\section{$\mathrm{mg} / \mathrm{dm} 3$}

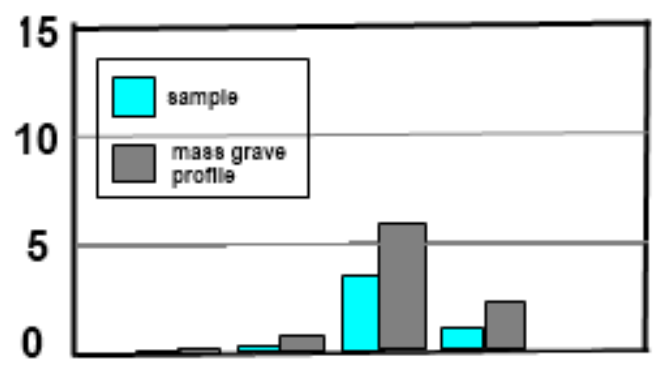

metal $\quad \mathrm{Cr} \quad \mathrm{Ni} \quad \mathrm{Cu} \quad \mathrm{Zn} \quad \mathrm{Cd}$

Figure 1. Content of chemical elements in the profiles of mass grave and from a sample place, Niepołomice (after Kaczmarek et al., 2017)

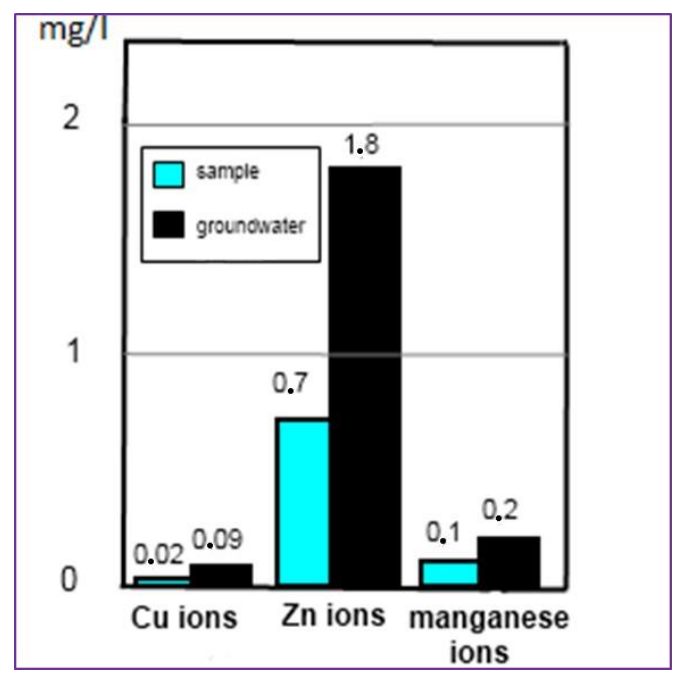

Figure 2. lons in groundwater under the mass grave in Niepołomice (after Kaczmarek et al., 2017)

A second mass burial from the First World War is the grave in Gorlice, located on the upper slope of the Cemetery Mountain was investigated by Zychowski (Zychowski, 2008). The substrate of this area is medium clay. In the samples from the wells located $60 \mathrm{~m}$ and 400 $\mathrm{m}$ from the burial, respectively, the content of zinc ions significantly exceeded the standards, both in the test and control sample. $\mathrm{Zn}$ ions in the sample near the grave reached $1.02 \mathrm{mg} / \mathrm{l}$, and from the comparative well $-1.15 \mathrm{mg} / \mathrm{l}$. The value of copper ions was surprisingly low $-0.02 \mathrm{mg} / \mathrm{l}$ and $0.04 \mathrm{mg} / \mathrm{l}$.

The mass grave of Glinik is a final example of a grave examined from the First World War and is located on a lower flattening of terraces and a silt-gravel substrate. The sample was taken from a well placed $15 \mathrm{~m}$ from the grave, and a control sample - from a waterhole located $200 \mathrm{~m}$ from the grave. The samples showed $507 \%$ and $440 \%$ of the permissible content of iron ions. A large amount of manganese, phosphorus and ammonium ions was also found that exceeded $100 \%$ of the permissible content in both the conifer sample and the test sample. Standards of zinc, chloride and sulphate were also exceeded (Zychowski, 2008).

\section{Conclusions}

The review of several studies of mass burials demonstrates the serious danger they pose because of the heavy metal hazard. Previous studies of the concentration of various chemical elements from individual graves clearly show the large impact that the decomposition of corpses and of metal objects in the grave have on the natural environment and on human health. Heavy metals, usually found in low natural concentrations, can pose a serious threat to all organisms around the mass grave where their concentrations are high. It has also been shown that the type of substrate and terrain, as well as the type of soil, have a huge impact on the rate of dispersion of these elements. There remains much research to be done regarding the consequences of improper placement of mass graves. This applies not only to the problems of mass war graves, but also to graves after natural disasters, epidemic, and even inadequately situated cemeteries.

\section{References}

Borczyk D. (2015), Podstawowe parametry wody, act 150806, Sekcja Higieny Środowiska.

Kabata-Pendias A. and Pendias H. (1999), Biochemia pierwiastków śladowych, Wydawnictwo Naukowe PWN, Warszawa.

Maczynska M., Pawlikowski M. and Zychowski J. (2006), Wyniki badań mineralogicznych i chemicznych grobu 104 i jego otoczenia, Materiały Archeologiczne, 36, 249-262.

Piontek M. and Fedyczak Z. (2014), Toksyczność miedzi, cynku oraz kadmu, rtęci i ołowiu dla człowieka, kręgowców i organizmów wodnych, Zeszyty Naukowe, 155, 70-83.

Regulation of the Minister of Health and Social Welfare of May 4 1990 on the quality of groundwater (Journal of Laws, No. 35, item 205).

Romanowska-Duda Z. (2013), Metale ciężkie jako specyficzne zanieczyszczenia środowiska wodnego, lecture paper, Uniwersytet Łódzki, Wydział Biologii i Ochrony Środowiska.

Środowiska K.A. (2010), Teoria do ćwiczeń laboratoryjnych. Monitoring jakości wody, Wydział Chemii, Uniwersytet Gdański.

Zychowski J. (2000), Wpływ lokalnego, holoceńskiego czynnika na jakość utworów terasy plejstoceńskiej, In: Transformacja 
dolin plejstoceńskich $w$ holocenie. Strefowość i piętrowość zjawiska, UŚ Wydział Nauk o Ziemi, pp. 127-130.

Zychowski J. (2005), Wpływ masowego grobu na zawartość wybranych bakterii I związków organicznych w wodzie gruntowej, Przeglad Geologiczny, 53/11, 1079.

Zychowski J. (2008), Wpływ masowych grobów z I i II wojny światowej na środowisko przyrodnicze, Wydawnictwo Naukowe AP, Kraków.

Zychowski J. and Bryndal T. (2015), Impact of cemeteries on groundwater contamination by bacteria and viruses - a review, Journal of Water and Health, 13/2, 285-301.

Zychowski J., Lach J. and Kolber M. (2000), Spatial changeability of ground waters chemism in the surroundings of cemeteries in South Poland, In: State and anthropogenic changes of water quality in Poland, Burchard J. (Ed.), Łódź.

Zychowski J., Lach J. and Kolber M. (2005a), The differentation of glycine, leucine and isoleucine contents in the ground water in cemeteries located on different bedrock, In: State and Anthropogenic Changes of Water Quality in Poland III, Burchard J. (Ed.), Łódź.

Zychowski J., Lach J. and Kolber M. (2005b), Wpływ podłoża masowego pochówku z II wojny światowej na chemizm wód gruntowych, Przeglqqd Geologiczny, 53/11, 1079-1080.

Zychowski J. Lach J. and Pawlikowski M. (2006), Produkty dekompozycji szczątków organicznych na przykładzie masowego grobu w Niepołomicach, Geologia, 32/2, 203-224. 